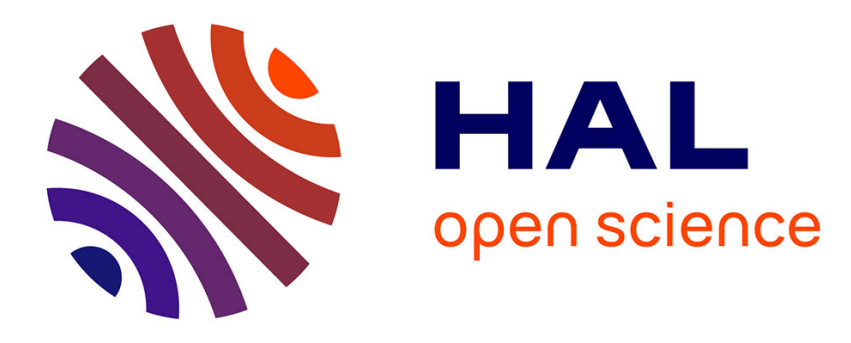

\title{
Treating hidradenitis suppurativa with photodynamic therapy
}

Serge Mordon

\section{To cite this version:}

Serge Mordon. Treating hidradenitis suppurativa with photodynamic therapy. Journal of Cosmetic and Laser Therapy, 2017. hal-02635160

\section{HAL Id: hal-02635160 \\ https://hal.science/hal-02635160}

Submitted on 27 May 2020

HAL is a multi-disciplinary open access archive for the deposit and dissemination of scientific research documents, whether they are published or not. The documents may come from teaching and research institutions in France or abroad, or from public or private research centers.
L'archive ouverte pluridisciplinaire HAL, est destinée au dépôt et à la diffusion de documents scientifiques de niveau recherche, publiés ou non, émanant des établissements d'enseignement et de recherche français ou étrangers, des laboratoires publics ou privés. 


\title{
Treating hidradenitis suppurativa with photodynamic therapy
}

\author{
Pr Serge Mordon \\ INSERM, Univ. Lille, CHU Lille, U1189-ONCO-THAI-Image Assisted Laser Therapy for \\ Oncology, Lille, France
}

\section{Contact: $\underline{\text { serge.mordon@inserm.fr }}$}

\begin{abstract}
Hidradenitis suppurativa is a chronic, recurring, and disabling inflammatory condition of the skin. There is no cure for hidradenitis suppurativa and treatment must be adapted to each individual patient. Several studies have been published since 2004 on the use of photodynamic therapy to treat hidradenitis suppurativa. The use of superficial or interstitial illumination with 5-Amino-Levulinic Acid (5-ALA) or methylene blue (MB) have been proposed. Injecting 5-ALA or MB followed by illumination with a fiber optic sensor placed inside the lesion appears to be a better method of treating these thick lesions.
\end{abstract}

\section{Introduction}

Hidradenitis suppurativa is a chronic, recurring, and disabling inflammatory condition of the skin. Although we do not know exactly what causes hidradenitis suppurativa, studies suggest that it may be attributable to specific abnormalities within the hair follicles. Hidradenitis suppurativa is related to dysfunctional follicular epithelial cells and commonly affects the skin in the armpits, below the breasts, and around the groin. Hidradenitis suppurativa affects between $1 \%$ and $4 \%$ of the population in Europe and is more common in women than in men, at a ratio of $4: 1$.

It occurs in a number of forms, which may vary from one person to the next. Mild cases present as small lumps, blackheads, or a few cysts, while the most severe cases can take the form of multiple and recurring abscesses that may leak foul-smelling pus (Figure 1). The lesions caused by hidradenitis suppurativa can be very uncomfortable and painful, and sufferers often find their quality of life is affected. 

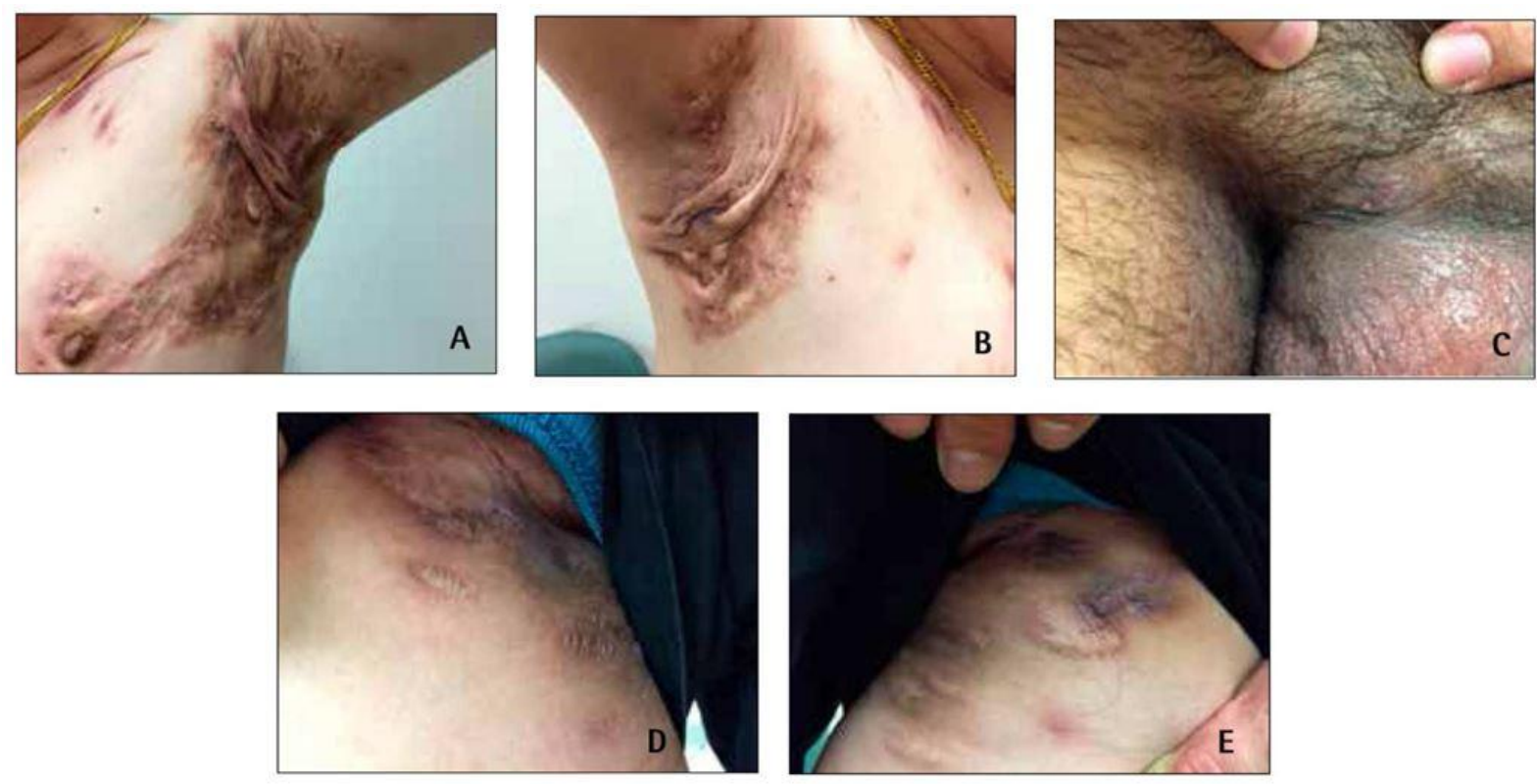

Figure1. Main sites of hidradenitis suppurativa. (A) and (B) Armpits: multiple interconnected sinus tracts and abscesses across the entire area, on both sides, Hurley Stage III. (C) Genital area: one single abscess with a sinus tract in the fold between the pubis and penis, Hurley Stage II. (D) and (E) Groin: diffuse interconnected sinus tracts across the entire area, with severe scarring on both sides, Hurley Stage III. (Data from Lee et al.) (9)

\section{Treating hidradenitis suppurativa}

There is no cure for hidradenitis suppurativa and treatment must be adapted to each individual patient, depending on the disease severity according to Hurley staging (1) (Table 1 and figure 2). Treatment is primarily aimed at preventing new lesions, providing early and effective treatment for newly formed lesions, and removing the existing nodules and sinus tracts. Standard practice is to offer nonmedical procedures, topical and systemic treatments, and surgery.

Several studies have been published since 2004 on the use of photodynamic therapy to treat hidradenitis suppurativa. The initial studies used the same protocol as for treating actinic keratosis, i.e., topical photodynamic therapy. More recently, the use of interstitial illumination and methylene blue (MB) have been proposed. 


\begin{tabular}{|c|c|c|c|c|}
\hline \multirow{2}{*}{$\begin{array}{l}\text { Hurley Clinical } \\
\text { Staging System }\end{array}$} & \multirow[t]{2}{*}{ Characteristics } & \multicolumn{3}{|c|}{ Recommended treatment } \\
\hline & & Non-medical & Pharmacological & Surgical \\
\hline Stage I (mild) & $\begin{array}{l}\text { Solidary or multiple } \\
\text { abscess formation } \\
\text { without scarring or } \\
\text { sinus tracts }\end{array}$ & $\begin{array}{l}\text { The following steps should be } \\
\text { considered regardless of the severity } \\
\text { of the hidradenitis } \\
\text { suppurativa (grade F, level III): } \\
\text { - Provide education, counseling, } \\
\text { and support } \\
\text { - Avoid skin trauma } \\
\text { - Encourage lifestyle } \\
\text { modifications, } \\
\text { including weight loss and quitting } \\
\text { smoking }\end{array}$ & $\begin{array}{l}\text { First-line treatments: } \\
\text { - Topical clindamycin (grade B, level II), } \\
\text { oral tetracycline (grade B, level II) } \\
\text { Second-line treatments: } \\
\text { - Topical resorcinol (grade F, level II), } \\
\text { hormonal therapy (grade F, level II), } \\
\text { intralesional corticosteroid injection } \\
\text { (grade F, level III) }\end{array}$ & $\begin{array}{l}\text { Incision and drainage (not } \\
\text { encouraged) }\end{array}$ \\
\hline Stage II (moderate) & $\begin{array}{l}\text { Recurrent abscesses } \\
\text { with sinus tracts and } \\
\text { scarring }\end{array}$ & & $\begin{array}{l}\text { First-line treatments: } \\
\text { - Topical clindamycin, oral tetracycline } \\
\text { Second-line treatments: } \\
\text { - Topical resorcinol, hormonal therapy, } \\
\text { intralesional corticosteroid injection } \\
\text { Third-line treatment: } \\
\text { - Refer to a dermatologist }\end{array}$ & $\begin{array}{l}\text { If multiple medical therapies } \\
\text { have failed, refer to a plastic } \\
\text { surgeon for excision }\end{array}$ \\
\hline Stage III (severe) & $\begin{array}{l}\text { Diffuse or multiple } \\
\text { interconnected sinus } \\
\text { tracts and abscesses } \\
\text { across the entire area }\end{array}$ & & $\begin{array}{l}\text { Refer to a dermatologist who might } \\
\text { initiate the following: } \\
\text { - Oral retinoids (grade F, level II) } \\
\text { - Immunosuppressive agents (grade F, } \\
\text { level II) } \\
\text { - Biologics (grade B, level I) }\end{array}$ & $\begin{array}{l}\text { If multiple medical therapies } \\
\text { have failed, refer to a plastic } \\
\text { surgeon for excision }\end{array}$ \\
\hline
\end{tabular}

Table 1: Recommendations for hidradenitis suppurativa treatment based on disease severity guided by the Hurley clinical staging system (Data from Lee et al.)

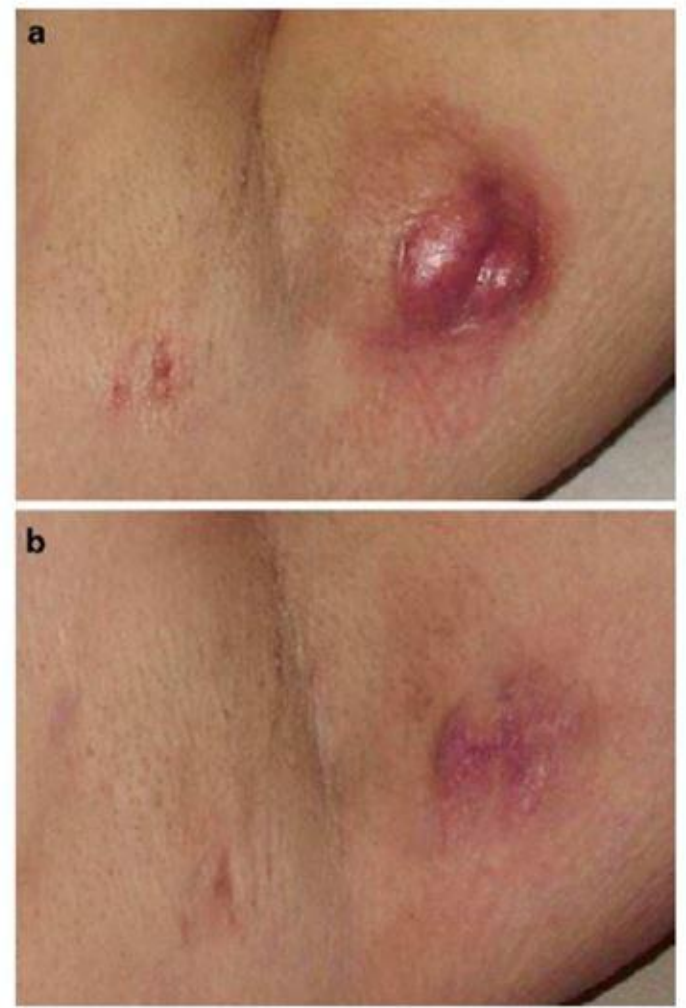

Figure 2: Clinical example of HS pre-PDT treatment (a) and post-PDT treatment (b) 5-ALAPDT treatment (10). 


\section{Photodynamic therapy with topical 5-ALA}

According to published articles, the technique used when treating the condition with PDT is similar to that used for actinic keratosis, i.e., MAL (Methyl AminoLevulinate)-PDT (PhotoDynamic Therapy) (MAL 16mg/g) under occlusion for 2.5 hours, and illumination with Aktilite ${ }^{\circledR}$ (PhotoCure ASA, Oslo, Norway) $37 \mathrm{~J} / \mathrm{cm}^{2}$ or Levulan $\bigodot$ in the USA with blue light. In this case, the incubation time is between 15 and 30 minutes and the blue light exposure lasts 18 minutes in order to reach a fluence of $10 \mathrm{~J} / \mathrm{cm}^{2}$.

A summary of the various studies using topical 5-animo-levulinic acid (5-ALA) was published by Agut-Busquet et al. in 2016 (2). Out of 12 articles, 8 were in favor of PDT and the other 4 did not report any response. Of these four articles, only one used blue light but with minimal penetration depth, which could explain why the treatment was not effective (3). Unfortunately, none of the studies were randomized and patient follow-up was usually limited to only 6 months.

\section{Intralesional photodynamic therapy (iPDT)}

5-ALA penetrates skin lesions poorly when applied topically. In fact, Maisch et al. observed the formation of PpIX in the skin at a maximum depth of only $100 \mu \mathrm{m}$ after a topical application of 5-ALA (4). It is therefore easy to see why this treatment has very limited clinical benefits for Stage II and III lesions. Valladares et al. thus suggested an intralesional injection of $1 \%$ 5-ALA in physiological serum. When injected, the 5-ALA penetrates directly into the lesions and so this is where the PpIX is produced (5). More recently, the same team used a 5\% 5-ALA gel (Intrala 1, IDP Light SL, Alicante, Spain). Lesions were incubated under an opaque dressing for two hours prior to illumination with a $400 \mu \mathrm{m}$ core optical fiber inserted into the lesion using a needle. This optical fiber was connected to a laser emitting 630 $\mathrm{nm}$ (Intermedic) at $1.2 \mathrm{~W}$, therefore delivering $180 \mathrm{~J} / \mathrm{cm}^{2}$ (Figure 3). Depending on the progression of the lesion, this treatment can be repeated after 5-7 weeks (6).

In a series of 38 patients treated with this Intralesional photodynamic therapy (iPDT) technique between 2011 and 2015, 29 achieved a complete response. The lesion persisted in eight patients, and there was one relapse. A complete response was obtained for $68.2 \%$ of armpit lesions, $88.5 \%$ of groin lesions, $88.9 \%$ of buttock lesions and $100 \%$ for other locations (Figure 4 and 5). Out of the 38 patients, 18 obtained a complete response after just one session and tolerated the treatment well (6). 
a

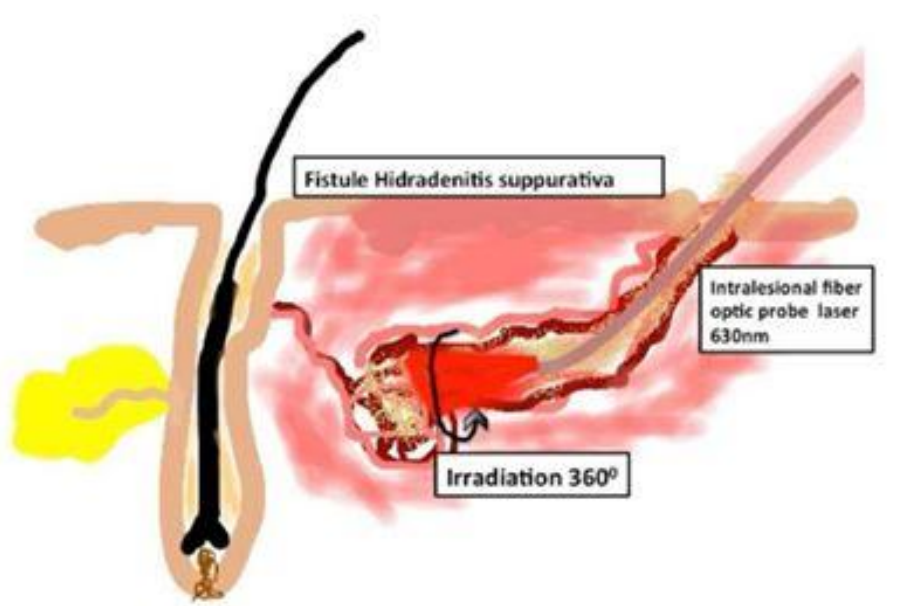

b

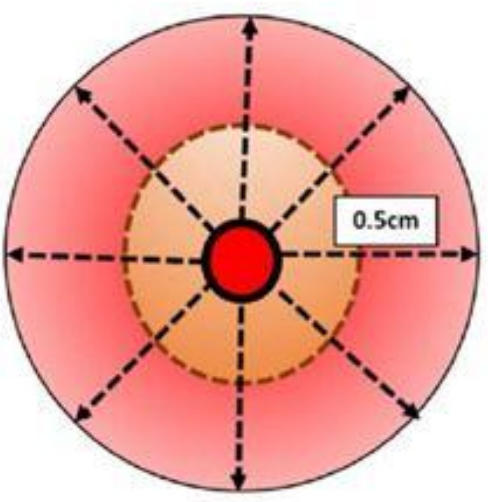

Figure 3: Diagram illustrating intralesional illumination using iPDT. (A) Irradiation following the natural path of the fistula with an intralesional fiber optic sensor. (B) Irradiation field encompassing the cavity filled with gel (brown) and inflamed tissue (pink) around the sensor $(\mathbf{6})$.

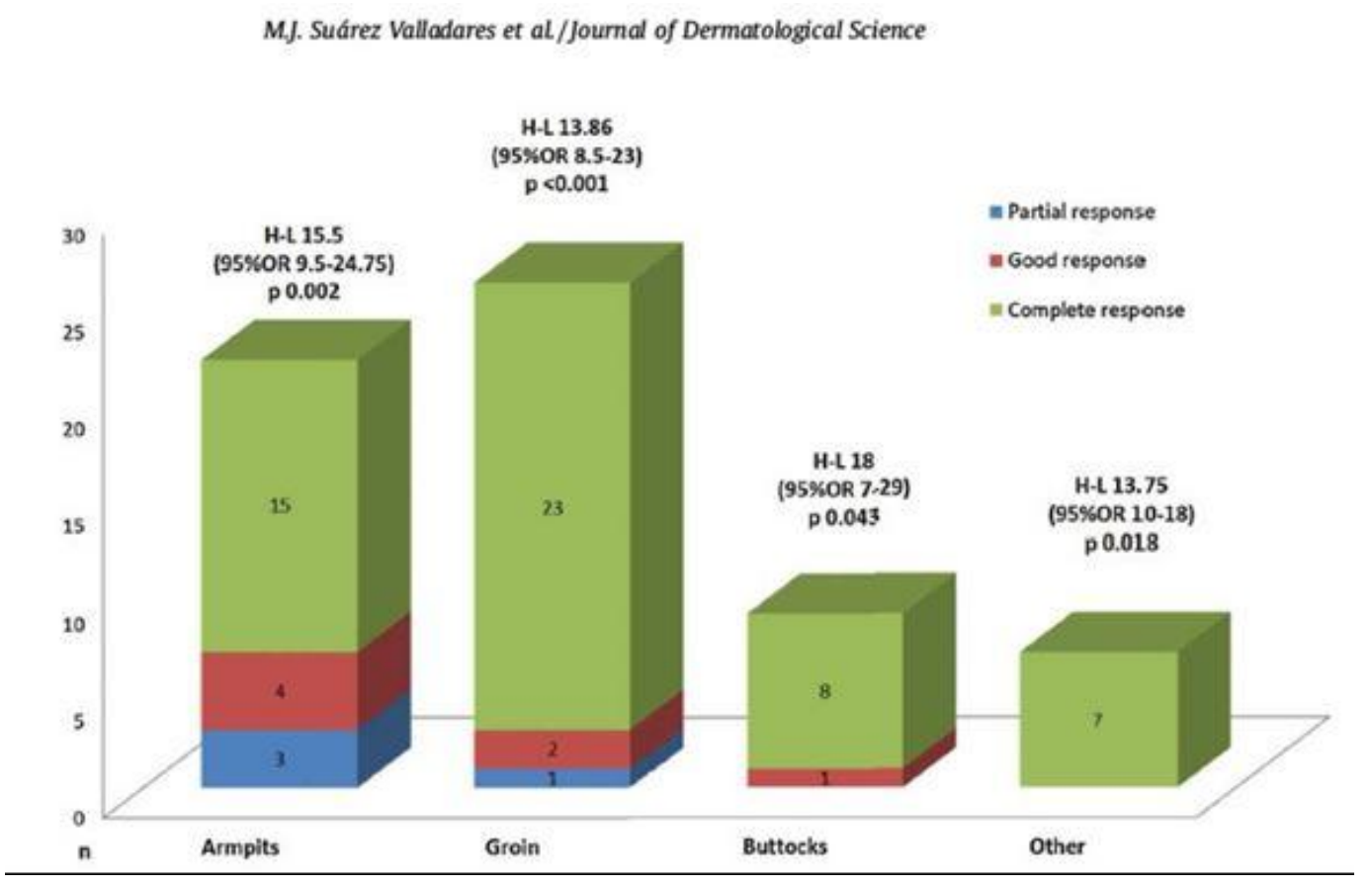

Figure 4: Results by location of lesions (6) 


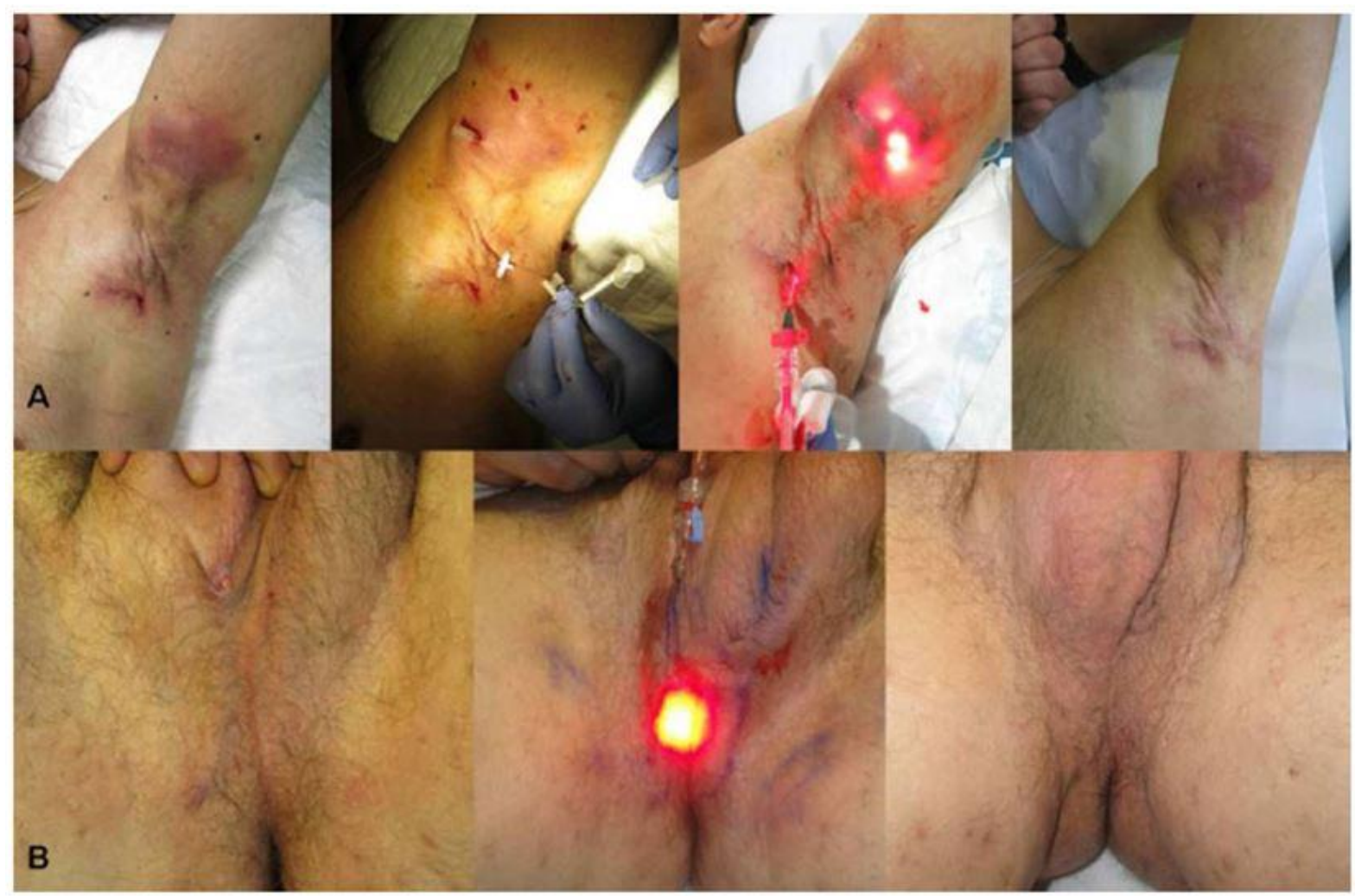

Figure 5: The best results were obtained with isolated fistulas and in the armpit and breast regions, and on the sacrum where the majority of the lesions were found (6)

\section{Methylene blue}

Both Fadel et al. and Agut-Busquet et al. recently conducted studies with MB (2,7). MB, which is non-toxic and inexpensive, is widely available at all hospital pharmacies because it is the first-line treatment for methemoglobinemia. It has a short incubation period of 5-20 minutes. When used in gel form, it appears to penetrate deeper into the lesions.

These two teams illuminated the lesions at $635 \mathrm{~nm}$. This was due to the fact that this wavelength had been developed for use with 5-ALA and was therefore available. However, the peak absorbance of MB is observed at $668 \mathrm{~nm}(\mathbf{8})$ (Figure 6).

Fadel's use of a pulsed flashlamp (EPI-C Plus; Espansione Group, Bologna, Italy) fitted with a $630 \mathrm{~nm}$ filter $(\mathbf{8}), 25 \mathrm{~cm}^{2}, 20 \mathrm{~ms}, 25 \mathrm{~J} / \mathrm{cm}^{2}$ also calls into question the action of photodynamic therapy compared to selective thermal action. 
The 10 patients treated by Fadel (seven women, three men) received an average of eight sessions of IPL. The lesions beneath the breasts responded faster than those in the groin or on the buttocks. Moderate improvement was achieved for Stage III lesions (Figure 7)

In the study by Agut-Busquet et al., the photosensitizer was a 1\% MB solution injected into the lesion under ultrasound guidance until the lesion turned dark blue. After a 15-minute incubation period, the lesions were illuminated with an Aktilite ${ }^{\circledR}$ device (Galderma) or BFRhodoLED® lamp (Biofrontera) with the same parameters as for 5-ALA: $37 \mathrm{~J} / \mathrm{cm}^{2}$ for each lesion (average irradiation time of eight minutes) (Figure 8). A total of seven patients were treated: two received only one session, the other five received two sessions spaced 15 days apart. Patient follow-up was at 1, 2, 4 and 6 months.

A good response was seen in six patients after 1 month. At 6 months, 5 patients $(71 \%)$ were in remission in the treated area. These preliminary results with MB are interesting, especially since the illumination parameters were suboptimal.

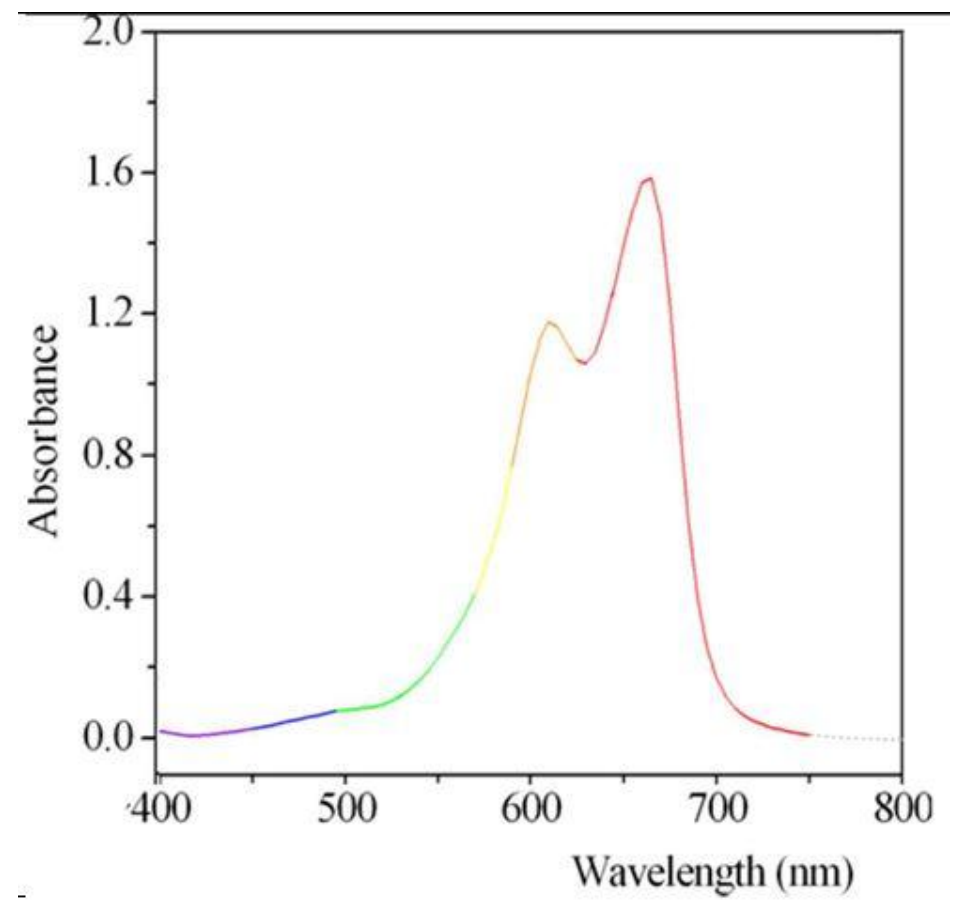

Figure 6: Absorption spectrum of methylene blue. The peak is at $668 \mathrm{~nm}(\mathbf{8})$ 

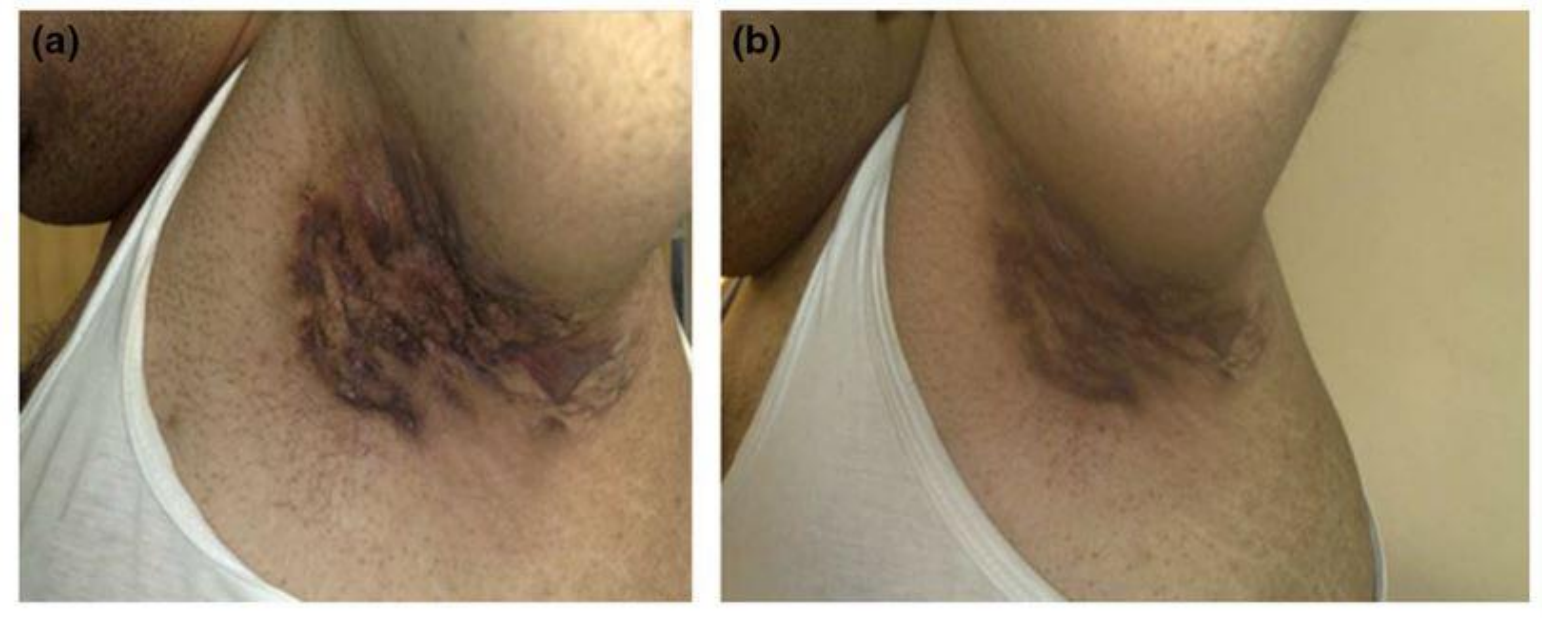

Figure 7: Stage III hidradenitis suppurativa in a male patient (A) before treatment; (B) only moderate improvement was achieved after 12 treatments due to the fibrosis and scarring (Fadel et al.) (7).
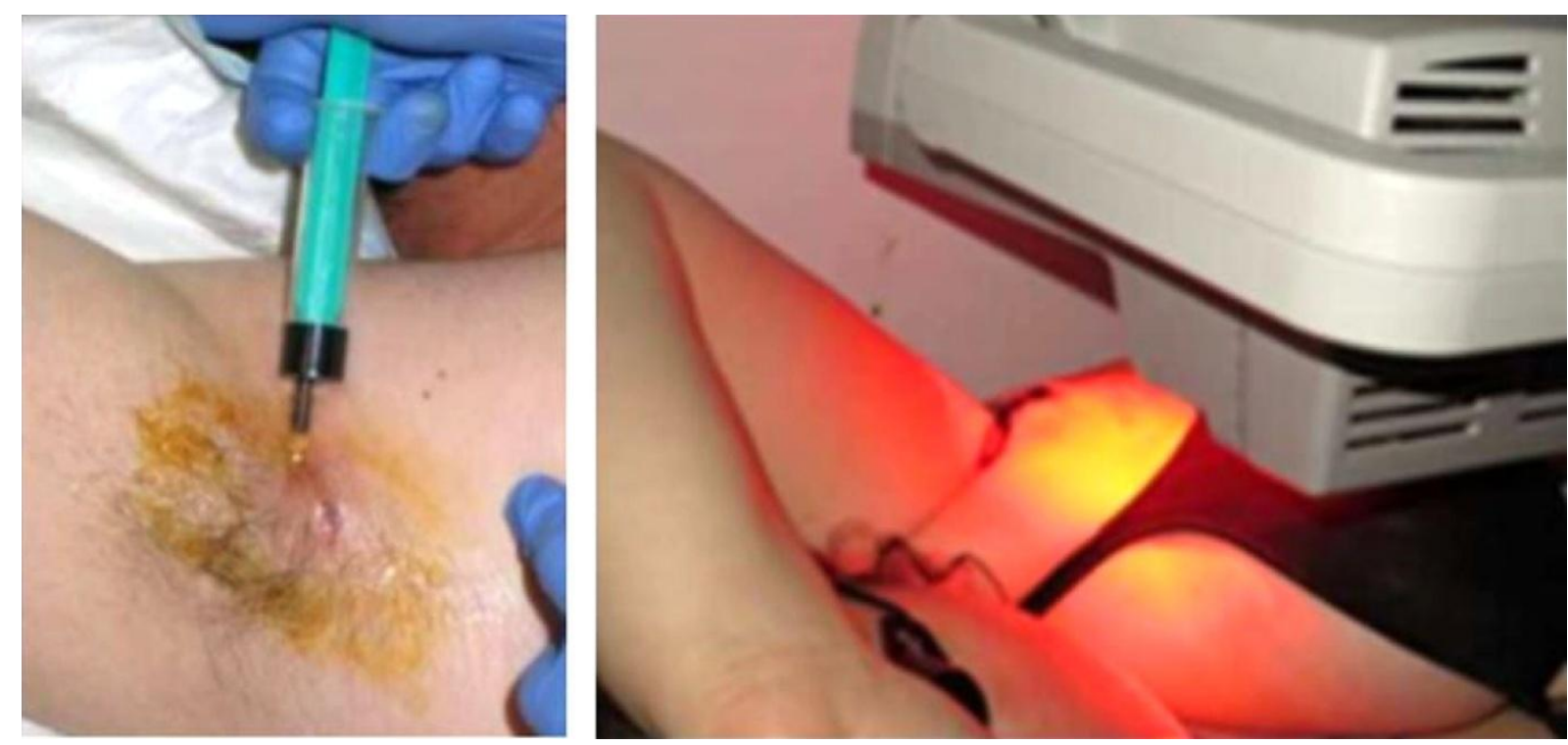

Figure 8: Images of the procedure. Intralesional administration of methylene blue followed by illumination with a $635 \mathrm{~nm}$ light-emitting diode (Agut-Busquet et al.) (2). 


\section{Conclusion}

Recent results from using iPDT to treat hidradenitis suppurativa have been highly promising. Injecting 5-ALA or MB followed by illumination with a fiber optic sensor placed inside the lesion appears to be a better method of treating these thick lesions.

\section{References}

1 Revuz J. Évaluation clinique de la sévérité de l'hidradénite suppurée - maladie de Verneuil, Ann Dermatol Venereol. 2015 Dec;142(12):729-35

2 Agut-Busquet E, Romaní J, Gilaberte Y, García-Malinis A, Ribera-Pibernat M, Luelmo J. Photodynamic therapy with intralesional methylene blue and a $635 \mathrm{~nm}$ light-emitting diode lamp in hidradenitis suppurativa: a retrospective follow-up study in 7 patients and a review of the literature. Photochem Photobiol Sci. 2016 Aug 4;15(8):1020-8.

3 Gold M, Bridges TM, Bradshaw VL, Boring M. ALA-PDT and blue light therapy for hidradenitis suppurativa. J Drugs Dermatol. 2004 Jan-Feb;3(1Suppl):S32-5

4 Maisch T, Santarelli F, Schreml S, Babilas P, Szeimies RM. Fluorescence induction of protoporphyrin IX by a new 5-aminolevulinic acid nanoemulsion used for photodynamic therapy in a full-thickness ex vivo skin model. Exp Dermatol. 2010 Aug;19(8):e302-5.

5 Valladares-Narganes LM, Rodríguez-Prieto MA, Blanco-Suárez MD, Rodríguez-Lage, García-Doval I. Treatment of hidradenitis suppurativa with intralesional photodynamic therapy using a laser diode attached to an optical cable: a promising new approach. $\mathrm{Br} \mathbf{J}$ of Dermatol 2015; 172: 1136-39.

6 Suárez Valladares MJ, Eiris Salvado N, Rodríguez Prieto MA. Treatment of hidradenitis suppurativa with intralesional photodynamic therapy with 5-aminolevulinic acid and $630 \mathrm{~nm}$ laser beam. J Dermatol Sci. 2017 Mar;85(3):241-46.

7 Fadel MA, Tawfik AA. New topical photodynamic therapy for treatment of hidradenitis suppurativa using methylene blue niosomal gel: a single-blind, randomized, comparative study. Clin Exp Dermatol. 2015 Mar;40(2):116-22. 
8 Mordon S, Sumian C, Devoisselle JM. Site-specific methylene blue delivery to pilosebaceous structures using highly porous nylon microspheres: an experimental evaluation. Lasers Surg Med. 2003;33(2):119-25.

9 Lee EY, Alhusayen R, Lansang P, Shear N, Yeung J. Qu'est-ce que l'hidradénite suppurée ? Can Fam Physician. 2017 Feb;63(2):e86-e93.

10 Gold M.H., Photodynamic Therapy for Hidradenitis Suppurativa, Chapter 5, in Photodynamic Therapy in Dermatology. Mh G, Editor. Springer, New York, NY, 2011; ISBN 978-1-4419-1298-5 
